The 9th International Symposium on Automation and Robotics in Construction June 3-5, 1992 Tokyo, Japan

\title{
CURRENT STATUS OF AUTOMATION AND ROBOTICS IN CONSTRUCTION IN GERMANY
}

\author{
M.C. Wanner \\ FhG - IPA Stuttgart \\ Nobelstr. 12 \\ 7000 Stuttgart 80 \\ Germany
}

\begin{abstract}
This paper gives a brief overview of current developments and trends in automation and robotics in construction. Specific machines are outlined. An overview of national and international R\&D-projects is given.
\end{abstract}

\section{INTRODUCTION}

From 1988 to 1991 the construction machine manufacturers realized a sharp increase in production volume and turnover. This recent trend has now slowed down, although a major recession is not expected in that area.

Some significant steps forward for more automation and robotics in construction can be observed but also setbacks. The main problem is still the acceptance of those systems by the end user.

\section{TECHNOLOGY DEVELOPMENTS AND TRENDS}

With conventional construction machinery process monitoring, diagnostics and improved man-machine interfaces remain in the center of the recent developments. Some standardization trends, especially with bus systems and sensors can be observed with the national group of machine manufacturers.

Specialized machines and processes from selected companies have achieved a very high technical level. However, it is only fair to conclude that we do not have such a strong overall approach comparable to the one in Japan.

\section{APPLICATION RELATED DEVELOPMENTS}

\subsection{Excavation}

In Germany we have two major manufacturers who offer automated excavation within their product range $/ 1 /, / 2 /$. Both companies offer products with very similar features:

- Hydraulic pump management to control the energy in relation to the requirements;

- computer assisted loading with Teach-In and automatic execution of that movement;

- computer assisted profiling by means of an external sensor system and a specific controller.

In both cases we have individual controllers linked together on a multiprocessor bus system. The controllers can be shaped according to the customer's requirements. Most of the machines of the recent production are equipped with at least one of these features. 


\subsection{Earthworks}

With earthworks we have to consider loaders, dozers, graders and dumpers. The already mentioned companies $/ 1 /, / 2 /$ are also active in this area with their modular controllers.

With graders we have

- moldboard control (slope, angle, external control by laser);

- anti-slip control by radar or sonar;

- front wheel electronic drive control.

With loaders we have

- torque converters to optimize fuel consumption and shifting quality.

With dumpers we have

- controllers to optimize fuel-saving or a power programm for high driving performance on difficult terrain.

As in the case with excavators the features mentioned above are already integrated in the product range of the manufacturers.

\subsection{Road construction}

Automatic levelling for road pavers was developed in the 60 ies. These mechanisms were further improved with controllers and servo valves to achieve better qualities /3/. One major company in Germany is quite active in this field. Their developments will continue with automated navigation in the frame-work of an ESPRIT-project.

\subsection{Concrete distribution}

In Germany we have one company /4/ being active since 1985 in the development to control large reach manipulators with rotatory axis. This development has now reached the status of industrial prototypes with the following specific features:

- manual joystick control in the cartesian space;

- automated programm cycles;

- integration of peripherial functions (e.g. concrete pump, outriggers) into the basic controller;

- radio remote control.

The above mentioned machines do have, in addition, all functions of an industrial robot. The marketing of this product has already started.

This development has now been followed by another manufacturer to some extend.

\subsection{Telescopic cranes}

With telescopic cranes we have one manufacturer /5/ who is active in the field of electronics. The controller has a passive function and consists of the following main features:

- Load limitation control;

- measurement of the wind forces, warning to the operator;

- platform control;

- test, diagnostic and maintainance system.

The controller outlined above is a standard feature of larger telescopic cranes.

\subsection{Concrete panel fabrication}

Besides the outdated plants in Eastern Germany we have one manufacturer /6/ who is quite successful with his so called 'Concrete plant 2000'-concept. This approach which has achieved high industrial standard integrates design, time scheduling and fabrication with highly automated stations in an overall CIM-structure. For the placement of reinforcement 
two robots are in operation per plant.

\subsection{Brickworks}

With brickworks we have to distinguish between outdoor handling and stationary plant manufacturing.

With outdoor handling we have simple manipulators /7/ or small mobile cranes. These machines are in operation in very high numbers. More advanced concepts (navigation robots) currently developed at two universities still require their first field test.

With stationary plants we have at least three different concepts in operation - one of them $/ 8$ / was quite successful in marketing. In all cases the placement of the bricks and mortar is automated to a very large extend.

Regarding navigation tilesetting or plastering robots we do not have any initiative here in Germany.

\subsection{Tunneling}

For concrete applications in tunnels we use in all cases manual operated machines without electronics. One major drive forward to robotics could come from a coalmine application /9/. The efforts of German industrial companies are terribly slow.

With tübbing handling and microtunneling /10/ Germany is well within the international state of the art.

Robots for inspection and repair of concrete sewers $/ 11 /$ are in industrial use since several years - a lot of companies entered this interesting market.

The robot to repair brick sewers /12/ was further improved since the last year - although the developments were much delayed due to the lack of resources.

\subsection{Nuclear Applications}

The decommissioning of the nuclear power station Niederaichbach continues with several robots /13/. Further applications and new developments can be expected shortly.

\section{STATUS AT THE UNIVERSITIES AND RESEARCH ORGANIZATIONS}

A major programme which was planned for the next years to cover research in our area at the universities was cancelled. This very serious setback was compensated to some extend by European ESPRIT- and BRITEprojects.

For the bigger research organizations like IPA or $\mathrm{KfK}$ the question of funds also became serious to continue with the work as planned.

In the longer term prospect, however, it is clear that the basis established so far here in Germany is strong enough to compensate smaller setbacks.

\section{SUMMARY}

In Germany we have a slow progress forward. Some areas like excavators, road construction machines, concrete distribution, brick handling and nuclear applications are quite advanced.

The low risk approach is still very popular with end-users and machine manufacturers. 
REFERENCES

/1/ Leidinger, G: Application of electro-hydraulic control systems with earth moving machinery, 8th ISARC 1991.

12/ Walzer, W: Electronic systems for modern construction machines, 8 th ISARC 1991.

/3/ Ulrich, A: Automatic levelling in road construction, 8th ISARC 1991.

14/ Benckert, $\mathrm{H}$ : Computer controlled concrete distribution, 8th ISARC 1991.

/5/ Morath, E: Die Litronic im Fahrzeugkran, VDBUM-Seminar 1991.

/6/ Orth, W: Computer controlled production in precast works 2000, 8 th ISARC 1991.

17/ Böhm, D: The mason's elevator-handling-machine, 8th ISARC 1991.

18/ Anliker et al.: Automation of design and construction of singlefamily houses of brickworks, 8th ISARC 1991.

19/ Maidl, B: Shotcrete robot for improving working conditions, 8 th ISARC 1991.

/10/ Herrenknecht, M.: Laser controlled machines for micro tunneling, 8 th ISARC 1991.

11/ Palaske, T.: Robots repair damaged drains, 8th ISARC 1991.

/12/ Müller, W. et al.: Manipulator system for the redevelopment of gaps in brick sewers, 8th ISARC 1991.

/13/ Grünanger, G.: Remotely-operated dismantling of the reactor internals at Niederaichbach power plant using manipulators, 8th ISARC 1991. 